\title{
Kuka omistaa ja kenet?
}

Juha Herkman (2005). Kaupallisen television ja iltapäivälehtien avoliitto. Median markkinoituminen ja televisioituminen. Vastapaino. 362 sivua.

Omistajajärjestelyt tulivat jäädäkseen myös suomalaiseen mediakenttään viimeistään kaupallisen television laajetessa 1990-luvulla. Siitä lähtien viestintätalo toisensa jälkeen on yhdistänyt voimansa saadakseen toiminnalleen oikeanlaista synergiaa. Median omistuksen vaikutusta on Suomessa tutkittu vähän. Aihe on ollut esillä pitkään, mutta empiirinen kokemus on jäänyt uupumaan.

Tutkija Juha Herkman on tarttunut väitöskirjassaan aiheeseen, jossa hän esittää omistuksella olevan vaikutusta sisältöihin. Herkmanin tarkastelun kohteena on erityisesti, millaista julkisuutta iltapäivälehdet eri televisiokanaville antoivat 1996-2001 välisenä aikana ja miten televisio on muokannut lehtiä. Herkmanin viitekehyksenä on Kaupallisen television ja iltapäivälehtien avoliitto-tutkimuksessaan viestinnän poliittinen taloustiede. Viestinnän poliittisessa taloustieteessä johtoajatuksena toimii Herkmanin mukaan se, että viestintää tulee tarkastella liiketoimintana.

Kriittinen analyysi rakentuu kirjassa kolmen tapaustutkimuksen pohjalta. Ensimmäinen käsittelee neljännen valtakunnallisen televisiokanavan aiheuttamaa kilpailua. Toisessa tapauksessa Herkman osoittaa kuinka Nelosen aloittaminen noteerattiin lehdistössä. Kol- mannessa tarkastelun kohteena on Ally McBeal-ohjelman saama julkisuus iltapäivälehdissä. Näiden esimerkkien avulla Herkman osoittaa kuinka tehokasta on hyödyntää oman konsernin viestin markkinoinnissa.

Herkman tarjoaa lukijalleen kattavan ja hyvin kirjoitetun kuvan Suomen mediakentän muutoksista tutkimusjaksonaan vuosina 1996-2001. Herkman käyttää tämän ajanjakson lltalehteä ja Ilta-Sanomia aineistonaan. Tutkimuksessa keskeistä onkin, mistä näiden iltapäivälehtien sisältö muodostuu. Erot hän tuo esiin tilastoanalyysillä, jonka avulla Herkman esittää miten lehdet käyttivät televisiojulkisuuteen liittyvää materiaalia.

\section{Lehdetkin ovat televisioituneet}

Herkman väittää, että 1990-luvun lopulla television ja lehtien välisessä vaikutussuhteessa kamppailu kääntyi television hyväksi; lehdissä voidaan puhua Herkmanin mukaan jopa sisällön televisioitumisesta. Televisioituminen onkin Herkmanin tutkimuksen avainsana: sen kautta Herkman tarkastelee globalisaatiota ja 1990-luvun syvää lamaa. Globalisaation liiketoiminnalle esittämät haasteet saivat aikaan fuusioitumisbuumin myös viestintäteollisuudessa.

Fuusioitumisen yhteydessä Herkman puhuu media-alan konsernisoitumisesta monopolien sijaan. Herkman kirjoittaa: "Sisällöntuotannossa on hyvä tiedostaa konsernikytkentöjen olemassaolo - ainakin, jos halutaan pitää kiinni riippumattomuuden ja objektiivisuuden vaikutelmasta." Oman konsernin menestyksen lisäksi lehti voi kirjoittaa siis myös konserninsa tappioista, mikäli asia on uutisoinnin arvoinen.

Kirja toimii erinomaisena tiivistelmänä median ja talouden välisen suhteen kehittymisestä ja niiden historiasta Suomessa 1990-luvun puolivälistä alkaen. Minut se ainakin sai kysymään: kuka omistaa ja kenet? Jotain jäi vielä uupumaan: Missä on se "näkymätön käsi", joka ohjaa mediasisältöjä ja kenelle tämä käsi kuuluu? Siinä on tutkittavaa kerrakseen.

JOONAS JOSEFSSON 